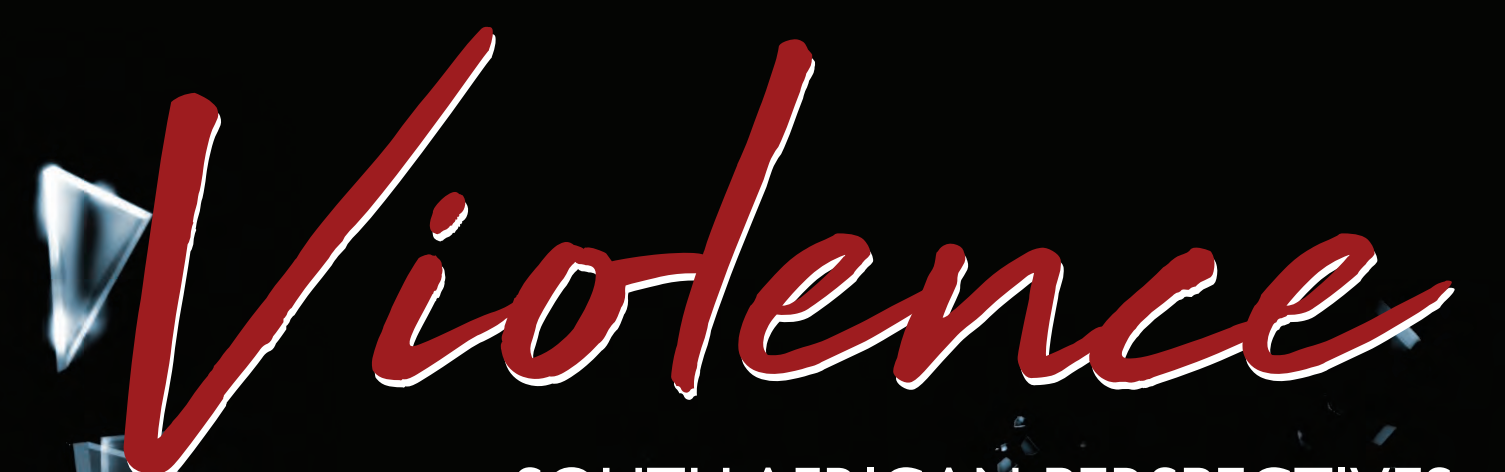

SOUTH,AFRICAN PERSPECTIVES

$\rightarrow$

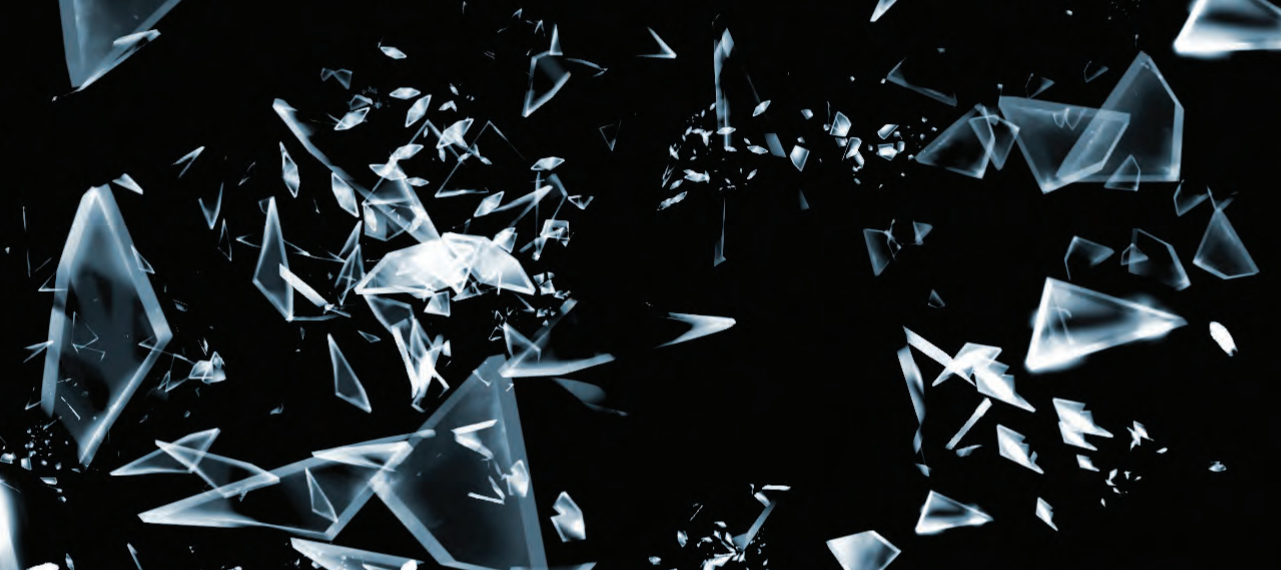

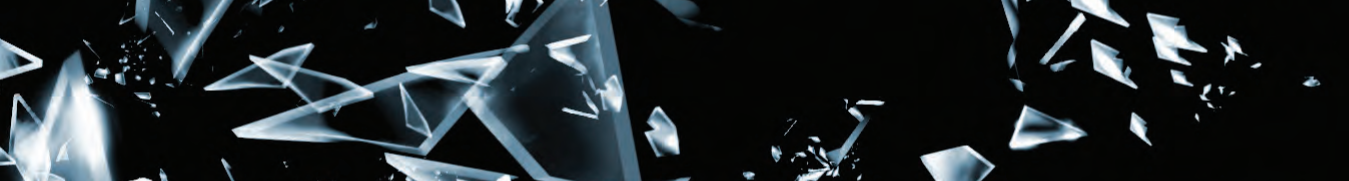

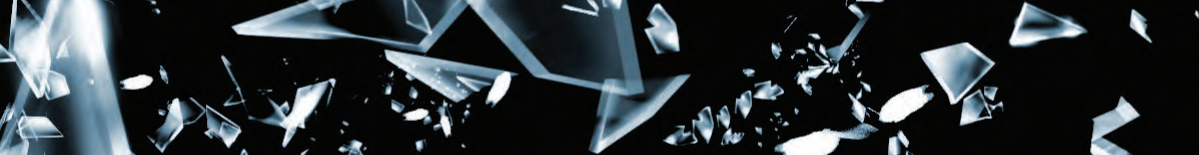

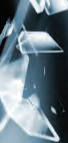

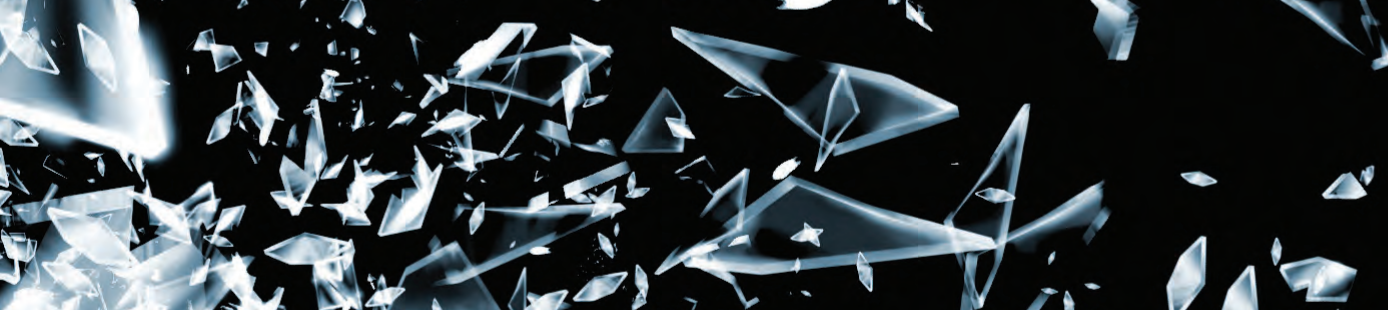

,

a 4 < 6

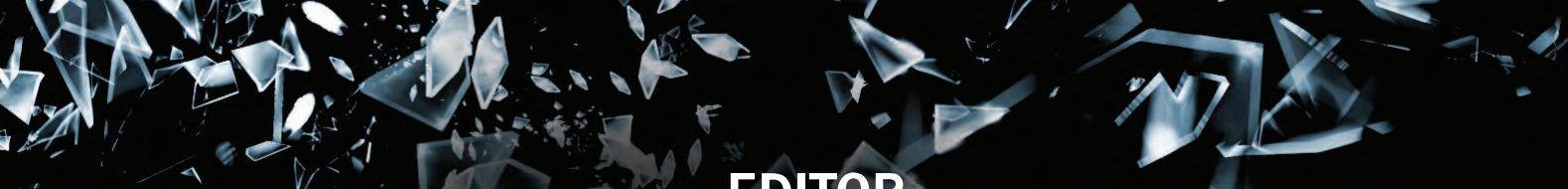

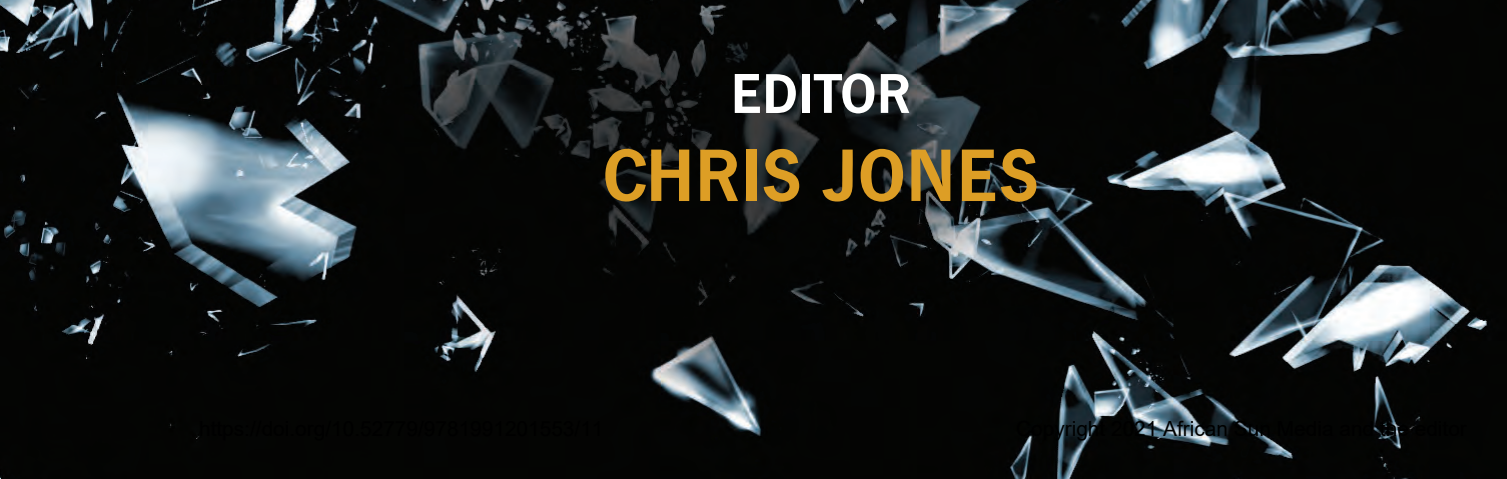




\title{
VIOLENCE \\ AND RELIGIONS
}

Sakkie Spangenberg

\begin{abstract}
"Where human beings are harmed by other human beings with some name of God on their lips, we must offer resistance, unmask and condemn, whether in our own ranks or in other confessions and religions."
\end{abstract}

(Gerstenberger 2002:298-299)

\section{Keywords}

Christianity; city states; empires; hunter-gatherers; ideologies; Judaism; Nicholas Wade; settler communities; state religion; violence; Yahwism

\section{INTRODUCTION}

Modern-day Christians who do not study their religion historically are often oblivious concerning the religious wars and violent acts that characterise the history of Christianity. Only those who are willing to read more than their Bibles and listen to more than the regular Sunday sermons will agree with the following statement of Kennedy (2006:25): "In the name of Jesus Christ, Christian devotees have launched crusades, slaughtered Jews, murdered Muslims, burned women as witches, tortured those hapless enough to be convicted of heresy, blessed battleships, and bombed abortion clinics."

Religious people often claim that they worship a god of love and forgiveness, not one of hate, violence, and death. They may refer to the golden rule "do unto others as you would have them do unto you" as a warrant for the claim that their religion promotes non-violence. However, confronted with the history of their religious tradition, they may acknowledge that there were times when adherents forsook the golden rule and acted contrary to what is believed to be the essence of their religious tradition. There are even books written to encourage believers to follow in the footsteps of those disciples, saints and wise teachers who were able to turn their backs on the violence inherent in their religious tradition, and to become broad-minded, to oppose the claim to absoluteness, and to embrace non-violence (cf. Bernhardt 1994; Berndt 2000).

We are thus confronted with the evidence that violence and non-violence characterise all religious traditions (Armstrong 2014). However, it seems as though violence more 
often than not trumps non-violence. This leaves one to question why this is the case. Why are religious people often reluctant to follow the golden rule? Why do they not shun violence but often embrace it? To be able to answer these questions, one must look at the evolutionary path of religions. The next section gives an overview of this path before the religions of ancient Israel (Yahwism), the Jewish people (Judaism) and Christians (Christianity) are discussed (keeping the evolutionary path in mind). The history of these religions will serve as material to reflect further on the problematic relationship that exists between religion and violence. The type of violence that this chapter will focus on is 'collective violence.' The objectives of collective violence throughout history have been political, economic, or social.

\section{THE EVOLUTIONARY PATH OF RELIGIONS}

To find an answer to the question of why some religious people revert to violence when their religion promotes peace, harmony, and goodwill, it is necessary to look at the origin of religions and how they developed and changed through the centuries.

\section{The religion of hunter-gatherer societies}

According to Wade (2010:39), "our apelike forebears" lived in small groups that were hierarchically structured and dominated by an alpha male. The authority of the alpha male was often challenged by other males and the alpha male was obliged to react. Skirmishes ensued during which the males re-established the hierarchy in the group. Violence was thus part and parcel of these small groups of primitive Homo sapiens people.

Things changed for the better as soon as these groups evolved into hunter-gatherer communities. These communities consisted of between ten and thirty people who roamed around looking for food (Gerstenberger 2002:19). They organised themselves on a different principle - they became "completely egalitarian" (Wade 2010:39). Male domination was something of the past. It was in these egalitarian societies with people's ability to use language to express themselves that religious behaviour emerged. Music and dance became important activities fostering group cohesion. Community members also experienced dreams which convinced them that a spiritual world existed apart from the natural world. Long hours of music, song and dance led to trance experiences which convinced them that they could enter the spiritual world of their dreams. However, dreams were not reliable channels "of communication with the other world" and also not "adaptable to public ritual" (ibid:93). Trances therefore became the preferred way of entering the spiritual world and of establishing contact with spiritual beings. Music, dance and trance eventually laid the foundation of the religion of hunter-gatherer societies and improved group cohesion (ibid:78-97). Religious behaviour was thus expressed through music, dance, and trance experiences. Aggressive behaviour and violent acts which could maim community members 
decreased since all members had access to the spiritual world and none could claim superiority. Moreover, there was "no legal distinction between 'mine' and 'yours" since "everyone shared common possessions" (Gerstenberger 2002:25).

However, these hunter-gatherer groups sometimes engaged other hunter-gatherer groups to establish the borders of the area in which they roamed. In these situations, skirmishes and even bigger battles did occur. One could thus say that although ingroup violence was minimal out-group violence did occur. Concerning this, Wade writes the following:

Religious behavior evolved in a dangerous world, amid hunter gatherer societies that did not hesitate to attack and sometimes exterminate their neighbors. The groups whose members developed the strongest emotional ties among one another were best able to prevail. These ties, forged in religious training and ritual, embedded in human nature its contradictory qualities of self-restraint and aggressiveness.

(Wade 2010:251-252)

\section{The religion of settled communities}

For many centuries, humans survived in hunter-gatherer groups, but then came a time when these groups settled and started practising an early form of agriculture. This "revolution in human history" occurred around 10000 BCE in "the fertile crescent of the Near East" (Gerstenberger 2002:93). ${ }^{1}$ However, the hunter-gatherer religious practices could not address the new societal needs and time for singing, dancing and trance experiences decreased. The agriculturalists had to spend almost all their time working their fields and caring for the domesticated animals. The old religious practices had to morph into something new (Wade 2010:225). The realisation that the sun and moon played a role in the growth of their crops led to the veneration of these heavenly bodies. Wade (ibid:189) summarises the changes as follows: "They recentered their religion on the cycle of the seasons and the demands of planting and harvesting. The dances were entrained into agricultural festivals."

The religion changed in tandem with the change in the structure of society: "throughout history, religion has been repeatedly reshaped to serve new needs as the nature of society changed" (ibid:189). The egalitarianism of the hunter-gatherer groups disappeared and the "hierarchical side of human nature reasserted itself" (ibid:125). "Priests took over the organization of religious activities" and soon monopolised access to the spiritual world (ibid:190). Sanctuaries were built and a ruler class developed. The ruler class consisted either of priests, or of a local chief assisted by priests supporting his claim of being appointed by the gods. Temple states and city states came into being. Anyone living either in or near these states were regarded as citizens who had to obey the city rulers' laws and regulations.

1 This revolution happened at different times in different communities inhabiting different regions of the globe (Harari 2014:77-79). 


\section{The religion of the state}

'State religion' is the name given to the religion promoted by the ruler class of a city state or even a nation state. The 'hunter-gatherer religion' did not disappear in totality with the rise of state religion. It continued and functioned in the family context. It became the household or 'family religion.' "The family rites of passage - birth and circumcision, puberty, marriage, the transfer of the family blessing and burial - were among the central cultic events in the family sphere..." (Gerstenberger 2002:49). The 'state religion' on the other hand focused on issues like the god(s) who should be worshipped in the state temple, the seasonal festivals, and the monthly and daily sacrifices. The appointment of priests and their role in taxation of the citizens were also important issues. It should be remembered that the state temple "was sanctuary, treasury, court and archive" simultaneously (Coote \& Coote 1990:34). One of the main objectives during inter-state wars was to lay hands on the treasures deposited in the temple of the foe.

Over time rivalries between different city states increased. Religion and warfare became inseparable. Prior to an attack on a neighbouring or distant city state, the priests and citizens were obliged to perform specific rituals to ensure that their gods would grant them victory. Suffering a defeat could mean that the gods did not join the battle because someone or some group had aggrieved the gods, or that the gods were punishing them for past offenses (Carroll 1993:153).

\section{The religion of empires}

Homo sapiens entered a new phase in its history when empires were born. According to Harari (2014:194), "[t]he first empire about which we have definitive information was the Akkadian Empire of Sargon the Great (2250 BCE)." Some of the city states or local states united to form a bigger entity which could dominate a large area. The aim was to lay hold on the natural resources in the region, the goods that were manufactured, the farming produce, and even humans that could build storage houses and roads for travel and trade. Permanent armies also came into being and they were tasked to maintain peace and stability within the borders of the empire.

As described above, religions always played a role in uniting societies, whether these societies were hunter-gather ones, or early settler communities, or city states. However, with the birth of bigger states and empires, religions were often usurped and turned into ideologies that assisted the ruling elite in dominating the population and in enforcing one worldview on everyone. In a sense 'imperial religion' played the same role as family, settler, and city state religions. However, power now entered the brew, turning religions into dangerous ideologies. Hunt (2004:234) is correct in stating: "Power attracts conflict, the two are inseparable ... The largest Christian nation in Europe, the home of Martin Luther and Protestantism, gave the world the Holocaust itself, humankind's worst crime." Adolf Hitler strove to establish a Third 
Reich in Germany, and German Christianity (also called the 'German Church') was born - an aberration of the Christian religion (Metaxas 2014:69-71, 73-81).

\section{Societies need religion}

Wade (2010:276) argues that societies cannot function well without religion: "Religion expresses a society's collective wisdom, past and present, as to how its members should best behave in order to enhance the society's survival." This cannot, however, be claimed for empires since empires turn religions into ideologies and these ideologies do not always benefit the conquered countries and their diverse populations and cultures. Moreover, empires are brutal. "The standard imperial toolkit included wars, enslavement, deportation and genocide" (Harari 2014:193). Although empires bring peace and stability to a region, they tend to exploit conquered peoples and their countries. A strange fact which needs to be noted is that people currently do not look for "an alternative to empire but simply [for] a better empire" (Davidson 2018:231).

\section{THE RELIGIONS OF ISRAEL, THE JEWISH PEOPLE, AND CHRISTIANS}

This section will reflect on the history of the religion of Israel (Yahwism), the Jewish people (Judaism), and Christians (Christianity), since this may assist in understanding the problem of religion and violence. The insights of critical scholars studying these religions, as well as those of Gerstenberger (2002) and Wade (2010) referred to above, will serve as guidelines in narrating the religious history of these three groups and their religions. ${ }^{2}$

\section{The hunter-gatherer phase in the history of Israel}

There is no recollection of this phase in the history of Israel in the Bible. However, the stories of the patriarchs of the Israelite nation reflect groups of people who may be classified as sojourners and pastoralists (Gen. 12-36). These sojourners can be situated in a phase between classical hunter-gatherers and fully settled groups. The stories of the "founding fathers" of Israel can be interpreted as stories of family groups roaming in the area known as Canaan. ${ }^{3}$

Scholars studying the history of Israel regard the patriarchal stories as unhistorical "with many anachronistic details" (Grabbe 2007:53). To regard these stories as reflections of a hunter-gatherer phase in the history of Israel would be seen as unfounded. However, that such a phase did exist prior to a settlement phase cannot be discarded all together since all Homo sapiens groups pass through such a phase.

2 The narration differs from that of Hans Küng who does not distinguish between the religion of Israel (Yahwism) and the Jewish people (Judaism). However, his books on the three Abrahamitic religions: Judaism (Küng 1992), Christianity (Küng 1995) and Islam (Küng 2009) are invaluable sources for research into the topic of religion and violence.

3 Canaan is "the area on the western side of the Jordan" (Grabbe 2007:50). It may include the area known as Phoenicia as well (Grabbe 2007:51). 
The forebears of the Israelites must have been hunter-gatherers either in Canaan itself, or in other regions of the fertile crescent. The religion of the patriarchs can be labelled 'family religion' since the religious acts were practised in a family context. The god venerated is often named "the God of the fathers" (Ex. 4:4) and he is none other than the supreme god of the Canaanite 'El-religion' (Smith 2004:156).

\section{The early settler phase: The pre-monarchical period and tribal religion}

One can get a glimpse of the conquest of Canaan by reading the books of Joshua and Judges. ${ }^{4}$ However, these two books give two totally different pictures of the settlement. Different hypotheses have therefore been proposed to explain how the settlement took place in reality (cf. Gerstenberger 2002:111-115; McKenzie 2010:51-52). These days most scholars agree that the stories in the book of Judges present a more realistic picture of the early settler phase in the history of Israel than the book of Joshua. The settlement took some years to complete. In the book of Judges, we encounter chieftains or leaders of the different tribes who played a dominant role in the settlement events. It is also evident that the different tribes worshipped different gods and family members often acted as priests. Polytheism characterised this phase in the religious history of Israel (Smith 2004:25). Like all other ancient north-western Semitic groups, the ancient Israelite tribes believed that there was a supreme god (referred to as $E l$ ) who had a wife (referred to as Asherah) and many children. They formed a family of gods who were all worshipped or at least venerated.

The book of Judges contains some of the most horrific stories of violence in the Bible. These stories probably reflect the situation during the pre-monarchic period. It may have been a period of utter chaos when tribes turned against other tribes to gain a foothold in Canaan. 'Tribal religion' motivated people in committing heinous acts of violence during the tribes' struggle for dominance and survival (Gerstenberger 2002:155; McKenzie 2010:66-68).

The reason behind these outbreaks of violence during the twelfth and eleventh centuries was the political vacuum which the fall of the Hittite empire (to the north) and the dwindling power of the Egyptians (to the south) created in this part of the ancient Near East (Coote \& Coote 1990:22-23; McKenzie 2010:48-49). Throughout its history, this section of the globe remained an imperial bone of contention. It was either the empires to the north (Hittite, Assyrian, Babylonian, Persian, Hellenistic, Roman) or the empire to the south (Egypt) which tried to stamp its authority on the territory and its inhabitants.

The conquest stories in Joshua are most relevant for a discussion of the topic "religions and violence". However, since the focus of the current chapter falls on the evolutionary path of religions in order to understand the issue of religion and violence better, the moral problems created by the conquest stories will not be addressed. Readers interested in this issue should read Collins (2005) and Collins (2019). 
Apart from the book of Joshua and Judges, the first book of Samuel also reflects a period when the Israelite tribes tried to establish themselves in Canaan. The focus in 1 Samuel falls on three main characters: Samuel, Saul, and David (McKenzie 2010:72). ${ }^{5}$ During Samuel's lifetime the tribes formed an alliance and Samuel acted as a leader as well as priest and prophet of the tribal alliance. The tribal alliance impacted on the religion of the tribes and the god Yahweh, initially only venerated by some tribes, ousted the supreme god El of the Canaanite religion and became head of the Israelite pantheon. The religion of Israel (Yahwism) came into being and can be clearly distinguished from the religion of the Canaanites. The religion of Israel entered a supersessionist phase in its history similar to the supersessionist phase in Christianity when the latter severed its ties with Judaism at the end of the 1st century CE. This time Yahwism severed its ties with the El-religion of the Canaanites (Keel 1995:95-113). Carroll (1991:113) remarks as follows: "What the Jews did to the Canaanites in the Hebrew Bible, the Christians did to the Jews in the New Testament."

In one of the stories concerning a battle between the Israelite tribes and the Philistines (1 Sam. 4-7) the ark of Yahweh played an interesting role. Some of the Israelite tribes requested that the palanquin of Yahweh stationed in the sanctuary at Shiloh, should be brought to the battlefield. The belief behind this request was that the Israelite tribes would fight more courageously since their warrior-god (Yahweh) will be present on the battlefield. However, they lost the battle and the ark fell into the hands of the Philistines - a sign of Yahweh's displeasure with them. Throughout the Old Testament we encounter this warrior-god who is able to cause destruction and death (Carroll 1993:156). ${ }^{6}$

Shortly after their defeat, the tribes requested Samuel to appoint a king so that there could be better cohesion amongst the tribes (1 Sam. 8). Saul was subsequently elected and appointed as king. However, when Saul suffered a defeat against the Amalekites he fell into disrepute as leader and king, soon to die a tragic death in battle (1 Sam. 31:1-6). David was then appointed as king.

\section{The later settler phase: The monarchical period and state religion}

David first became king of the southern tribes and a year or two later, king of the northern tribes as well (2 Sam. 5). He succeeded in keeping the Philistines at bay and also conquered the city of Jerusalem which was still in Jebusite hands. He turned

5 In 1 Samuel 1-7, Samuel is the main character, 1 Samuel 8-15 focuses on Saul and 1 Samuel 16-31 concerns David.

6 Gerstenberger (2002:151-156) opines that the conviction that Yahweh was a warrior-god was primarily cherished during the settlement period when the tribes had to fight for survival. Carroll (1993:155-158) and Collins (2019:147), however, do not agree with this view and argue that Israel believed in Yahweh as a warrior-god until late in its history. Isaiah 63:3 (a text from Trito-Isaiah) may serve as warrant for this viewpoint. 
this city into his personal capital. Reading the stories about David, in 2 Samuel and 1 Kings, one cannot but recognise the following pattern: "A prominent man who stands in the way of David's acquisition or maintenance of power dies violently" (McKenzie 2010:87). David was indeed a violent king who did not hesitate to get rid of his opponents. Furthermore, he and his son Solomon played a leading role in establishing the kingdom and in making Yahwism the state religion of Israel. This was possible because of a brief period of release from imperial pincers during the 10th century BCE. There was no imperial threat either from the north or the south.

Two ideologies soon developed: $(1)^{7}$ There will always be a descendant of David on the throne in Jerusalem (cf. 2 Sam. 7:4-17; 1 Kgs. 8:25). (2) No enemy will ever be able to conquer Jerusalem since Yahweh's temple will protect the city (1 Kgs. 8:44, 48; Jer. 7). The ideologies can be called the 'Davidic-scion ideology' and the 'Zion-temple ideology' (Nicholson 1967:95-96). Both stamped the history of Israel and Judah. ${ }^{8}$

The state religion of David and Solomon (called Yahwism) left room for the worship of a number of deities since the Israelite religion looked similar to that of other northwest Semitic peoples (Niehr 1995:71-72; Smith 2004:101-110). They believed that a four-tier pantheon of gods existed. Yahweh was the supreme god. He had a wife (called Asherah). Below them were their children, or lesser gods, and below them even lesser gods. On the lowest level were the messengers of the gods (sometimes referred to as "angels") (Handy 1995:27-43; Smith 2004:110-114).

TABLE 11.1 The four-tier Yahweh pantheon

\begin{tabular}{|c|}
\hline The Four-Tier Yahweh Pantheon \\
\hline Yahweh and his Asherah \\
\hline Children of the gods \\
\hline Other lower ranking gods \\
\hline Messengers \\
\hline
\end{tabular}

The alliance between the northern and southern tribes forged by David, did not last long. Shortly after Solomon's death the northern tribes went their own way and established their own kingdom called 'Israel'. This southern kingdom was called 'Judah'. The reason why the northern tribes severed their ties with the southern ones had to do with how the northern peoples were treated and the effects the state religion of David and Solomon had on their lives and traditions.

$7 \quad$ Also see Stoltenborgh, Bakermans-Kranenburg \& Van ljzendoorn (2013).

8 One of the difficulties in understanding the history of Israel and the religious history of Israel is the fact that the name 'Israel' is used for the 'united tribes', as well as for the northern kingdom which came into existence after 922 BCE when the northern tribes severed their ties with the southern ones. 
The state religion of David and Solomon did not succeed in fostering cohesion between the southern and northern tribes. David brought the ark of the covenant to Jerusalem and terminated the practice of allowing the palanquin to roam and be housed at other tribal sanctuaries. During the reign of Solomon, the construction of the Jerusalem temple was completed, and it became the royal sanctuary which dominated other tribal sanctuaries. Moreover, a hierarchy amongst the priests developed. The priests that functioned in the Jerusalem temple were ranked higher than the priests performing duties at the tribal sanctuaries. The northern tribes not only became disillusioned with the rule of Solomon, they also became convinced that state religion and state violence were simply two sides of the same coin. The outcome of their disillusionment was the termination of the agreement soon after Solomon's death (1 Kgs. 12). This remained the situation for two centuries until the northern kingdom was conquered by the Assyrian empire in 722 BCE.

For 200 years (922-722 BCE), two versions of Yahwism existed: a northern and a southern version and each had its own state temple and its own ideology. The northern version of Yahwism ceased to exist after the conquest of the Assyrians in 722 BCE. Only the southern version survived and was inscribed in the Hebrew Bible/Old Testament. However, during the onslaught of the Assyrians many northerners fled to the south and settled in Jerusalem. Amongst them were a group of prophets and writers who became known as the Deuteronomic group (Nicholson 1967:101-102).

During their first south-western campaign in the 8th century BCE, the Assyrians did not launch an attack on Jerusalem. The Judean kings wisely decided to rather enter into a treaty with the Assyrian king than try to be brave. Judah thus became a vassal state of the empire. One of the stipulations of the vassal-treaty they entered into was that the Assyrian gods should be venerated in the Jerusalem temple as well. A kind of syncretistic cult developed in Jerusalem which the Deuteronomic group and the Judean prophets abhorred. They found it unacceptable that Yahweh was now ranked on the same level as the Assyrian gods. The prophets campaigned to rid the temple of Assyrian cultic objects.

Yahwism slowly developed into a monotheistic religion during the 8th and 7th centuries BCE. Two Judean kings, Hezekiah (715-697 BCE) and Josiah (640-609 BCE), played prominent roles in this development (Smith 2004:60-61). They were influenced by the Deuteronomic group who fled the Assyrian onslaught on the northern kingdom and compiled a first draft of the book Deuteronomy in Jerusalem. They also tried to convince the Judean kings and elite to accept their outlook on Israel and Judah's history (Nicholson 1967:101-104). The document compared the relationship between Yahweh and Israel to a treaty. They got the idea of a treaty from the treaties the Assyrian kings concluded with the subjugated kings. The political treaty was called a 'vassal treaty', since the Assyrian king was referred to as the 'great king' while the 
subjugated king was named the 'vassal king.' The Deuteronomic group took Yahweh to be the 'great king' and the Israelite king and his subjects were the 'vassals'.

According to them, Yahweh agreed to protect Israel on condition that they worship him alone. Moreover, if they adhered to the stipulations of the treaty, Yahweh would protect and bless them. However, if they failed to do so, he would visit different types of curses on them (Dtn. 27-28). ${ }^{9}$

The ideology of the Deuteronomic group influenced king Hezekiah and king Josiah of Judah. Both launched religious reforms during their reigns. However, it was especially Josiah who bought into the ideology of the Deuteronomic group and Jeremiah who supported them. The threat of the Assyrians was long past by now, but a new empire loomed on the horizon - the Babylonian empire. The Judean king and his advisors cherished the hope that Yahweh would protect the small kingdom in the event of an attack by the Babylonian empire. The prophets emphasised that the Judeans should adhere to the stipulations of the Yahweh-treaty. 'Polytheistic Yahwism' thus changed into 'mono-Yahwism' - a form of monolatry. ${ }^{10}$ Some scholars refer to the group who encouraged the Judeans to become mono-Yahwists as the 'Yahweh-alone' party (Smith 1987:24-30). They convinced the Judeans to cease the worship of Asherah and other gods (2 Kgs. 23:4-6).

The Babylonian conquest of Jerusalem and the destruction of the temple in 586 BCE left the Judeans dumbstruck. Their symbolic world collapsed. The Judeans believed that no empire would ever be able to conquer Jerusalem (Jer. 7:4-8; 26:1-11). The conquest was a traumatic experience and those who survived began to question their faith tradition. The Deuteronomists (descendants of the Deuteronomic group) tried to explain the events. According to them the destruction of Jerusalem and the temple, not to mention the exile of many Judeans, were Yahweh's punishment for their disloyalty. They did not worship Yahweh alone, nor did they adhere to the stipulations of the covenant (Dtn. 12-26). Referring to the Israelite history, the Deuteronomists gave examples of how the Israelite and Judeans kings ignored the covenant. ${ }^{11}$ The impact of these events, as well as the reasoning of the Deuteronomists, had the outcome that the four-tier Yahweh-pantheon "imploded". Only Yahweh and his messengers remained (Smith 2004:114-119). 'Monolatric Yahwism' became 'monotheistic Yahwism. The exilic and post-exilic Yahweh-pantheon only had two tiers: Yahweh and his messengers (angels) (Handy 1995:42; Smith 2004:119).

9 The whole book of Deuteronomy has the format of a vassal-treaty. It has a historical introduction (Dtn. 1-11), the stipulations, or laws (Dtn. 12:1-26:15), mutual obligations (Dtn. 26:16-19), and the blessings and curses (Dtn. 27-28).

10 Becking (2001:192) describes monolatry as follows: "Monolatry' means the existence and value of other gods are recognised but their veneration by members of the community is dissuaded."

11 The Deuteronomic ideology is reflected in the so-called Deuteronomistic History (Deuteronomy to 2 Kings). The Deuteronomic group (often referred to as the Deuteronomists) revised the stories and imposed their ideology onto them. 
TABLE 11.2 The two-tier Yahweh pantheon

\section{The Two-Tier Yahweh Pantheon}

Yahweh

Messengers/angels

This new pantheon is vividly expressed in the message of Deutero-Isaiah (Isa. 40-55), the prophet who lived in exile in Babylon (586-539 BCE). In his oracles he mocks the Babylonian gods, maintaining that they are impotent and man-made (Isa. 41:6-7; 44:6-20; 46:1-13). Time and again, he proclaims that Yahweh is the sole creator and responsible for what is happening in the world (Isa. 45:1-8). What is reflected in these prophecies is the beginning of 'exclusivistic Yahwism. The existence of other gods alongside Yahweh were negated although the existence of angels was still acknowledged.

\section{Yahwism morphed into Early Judaism}

When the Persian empire eventually conquered the Babylonian empire and Cyrus, the Persian king, decreed that the exiles may return to their home countries in 539 BCE, 'exclusivistic Yahwism' was entrenched in the minds and religious practices of the exiled Judeans. The returnees brought these convictions with them to Yehud - the small Jewish province of the Persian empire located in Palestine. The Persians allowed them to rebuild Jerusalem and the temple and to practise their religion as long as they venerated the Persian gods as well and paid their taxes. The inhabitants of this province were now called Jews. Circumcision, observance of the sabbath, and the dietary laws which assisted the Judeans in surviving the Babylonian exile (586-539 BCE) became identity markers of being Jewish for the next centuries. 'Exlusivistic Yahwism' slowly morphed into 'Early Judaism.'12

The Assyrian, Babylonian and Persian empires impacted on the religious convictions of the Jews, and they had to adjust to the new circumstances (Gerstenberger 2002:151). Family religion was rekindled. The celebration of the sabbath, circumcision and dietary laws assisted them in surviving and remaining an identifiable group. The two ideologies that were prominent during the monarchical period, namely (1) the 'Davidic-scion ideology' and (2) the 'Zion-temple ideology' were suppressed but not totally abandoned. Some Jews kept on believing that somewhere in the future Yahweh will once again restore their freedom and a king from the Davidic family will reign the country. The 'Zion-temple ideology' received an incentive when the temple in Jerusalem was rebuilt and completed in 520 BCE and the daily sacrifices restored.

These changes may once again serve as warrants for Wade's argument that religions change as societies change. The Jews had to adjust their religious convictions during

12 One may also call it Second Temple Judaism. 
the Babylonian exile and the Persian rule. These changes had the good outcome that they assisted them in surviving and keeping their identity as a group. The changes also fostered group cohesion.

When Alexander the Great (356-323 BCE) succeeded in overpowering the Persians and conquered the ancient Near East in 333 BCE, hope once again flared up amongst the inhabitants of Yehud. This time round they may regain their independence. But this was not to be. For the next two centuries they remained subjects of either the Seleucids (Syrians heirs of Alexander's empire) or the Ptolemies (Egyptian heirs of Alexander's empire). For a brief period (167-163 BCE) the Jews managed to regain independence when the Maccabees staged a revolution against Antiochus IV, the Seleucid king who tried to impose his policies on them. But the independence did not last long before the Roman empire took control of Palestine in $63 \mathrm{BCE}$.

The Jews and the Romans never had a cordial relationship. One of the reasons being the appointment of Herod the Great (40-44 BCE) as client king in Palestine. Herod was an Edomite and not a full-blooded Jew. Herod managed to run Palestine fairly well, but after his death when his sons were appointed as client rulers, things started to fall apart. Two major wars broke out between the Jews and the Romans. One in 66-70 CE and the other in 132-135 CE and both had devastating outcomes for the Jews.

\section{Judaism, Christianity, and empires}

During the 1st century CE after the crucifixion of Jesus (33 CE), one could not distinguish between the two religious traditions which later became Rabbinic Judaism and Early Christianity. The early 'Christians' were Jews and they practised the Jewish religion known as Early Judaism. They worshipped in the temple in Jerusalem, circumcised their children, celebrated the Sabbath, and adhered to the dietary laws. However, Paul, a Hellenistic Jew, argued a case that thanks to Jesus's death and resurrection heathens could also become "sons of Abraham" without being circumcised. Moreover, these 'Jews' need not celebrate the Sabbath and adhere to all the Jewish dietary laws. A different kind of 'Judaism' was born - Judaism for the Hellenistic-Roman world. One which can be labelled 'inclusivistic Judaism' since it opened its gates to people from other cultural groups. Over and against this group stood those Jews who practised 'exclusivistic Judaism'. This group remained true to the Jewish cultural heritage and religious practices and was soon to become 'Rabbinic Judaism.'

\section{Judaism}

After the Jewish-Roman wars, the relationship between the two religious groups broke down. The inclusivists became early Christians while the exclusivists became Rabbinic Judaism. All Jews were forbidden to enter Jerusalem after the Second Jewish War (132-135 CE) and the Jewish leaders had to reflect on the future format 
of their religion. They rekindled the old 'family/community religion'. Synagogues were established where the Hebrew scriptures could be studied and discussed, while Jewish customs and festivals were celebrated in a family and community context. Gerstenberger remarks as follows:

\begin{abstract}
After the last vain rebellions against the power of the Roman state (70 and $135 \mathrm{CE})$, Judaism did not again become a state religion, but remained limited to school and community theology ... [l]t has been spared the orthodoxies and the persecutions of heretics that have taken place in the state and the centralized church. It has also been spared the formation of exclusivist dogmas. There has been neither crusades, nor inquisitions nor the burning of witches in the Jewish communities.

$(2002: 82)^{13}$
\end{abstract}

However, since the establishment of the modern state of Israel in 1948, a civil religion developed in Israel similar to the state religion of old. This civil religion laid claim to the promises the god of the fathers made to Abraham, Isaac and Jacob concerning the land of Canaan. The subsequent Israeli-governments violently drove the Palestinian Arabs from their estates in Palestine (Pappe 2009:122-229). Moreover, Israel as a state has been supported by the US-governments since its establishment. The US supports Israel unconditionally and "at the cost of Palestinian integrity" (Coote \& Coote 1990:164). Although there are Jewish groups who do not agree with the acts of the Israeli-governments, most adherents of Judaism support the Israeli-governments' claim to the land and would argue along these lines: God promised Abraham this land, we are his descendants, so the land is ours. The Tenakh says so (cf. Hunt 2004:114). ${ }^{14}$

\title{
Christianity
}

The early Christians followed similar practices as the Jewish communities of the 1 st century CE. They continued meeting in houses where they celebrated the death and resurrection of Jesus. However, within three centuries the religion of Jesus (early Judaism) was transformed into a pagan religion and a new understanding of God was born. This was the final break with Judaism and Hunt's description of what occurred in the 4th century is legitimate: "The Trinity just marks the point where Christianity stopped having much to do with the teachings of Jesus and modelled itself on contemporary pagan religion" (2004:220). Moreover, Christianity could no more claim to be a proper monotheistic religion - even though its theologians tried to argue a case for Christianity being monotheistic. One may even argue that Christianity reintroduced a pantheon on the basis of the vision of John in Revelations 4-5.

During the 3rd century, emperor Constantine (275-337 CE) decreed Christianity to be a legitimate religion of the Roman empire, while emperor Theodosius the Great

13 Emphasis added.

14 The Jewish people refer to the Hebrew Bible as the Tenakh which is an acronym for the three sections of the Hebrew Bible: Torah, Nebi'im, Khetubim. 
(346-395 CE) later decreed Christianity to be the sole official religion of the empire. Jews were suddenly accused of all sorts of wrongdoings and had to bear the brunt of imperial power and Christian theological convictions that their religion superseded Judaism and made it superfluous.

Jews were particular victims of the new regime. Christian-Jewish conflict grew during the late fourth century, and by 380s John Chrysostom denounced Jews and Judaising Christians in terms that would have a long and wrenching afterlife. John used the charge of deicide, holding the Jews guilty of the death of Christ, and thus of God himself, a theme later developed by Pope Leo.

(Jenkins 2010:120)

Christianity in its imperial dress was responsible for many wars and violence in Europe. Carrol gives a vivid description of what happened during the Crusades (1095-1271):

Under the banner of the cross Christians marched across Europe massacring Jews on the way to massacre Muslims in order to regain the holy places associated with Christian origins in the Holy Land. In the name of Christ, the giver of life, they brought death to many.

(Carroll 1991:92)

Three other examples may suffice to illustrate that Christianity has a history of violent and sometimes criminal acts as Deschner (1986) characterises them in his seven volume history of Christianity and violence: (1) The Thirty Years War (1618-1648) in Europe following the Protestant Reformation; (2) the colonisation of Africa when Christian Churches supported Europeans' land grabs and claims to their colonies' natural resources, and (3) the Great War (1914-1918) when Christian nations in Europe once again went to war in the summer of 1914. Concerning this war Jenkins (2014:70) says: "Religion mattered crucially in European politics in the age of coal and steam, of the maxim gun and the Krupp cannon." The different Christian nations vilified each other as part of their propaganda - Christians accusing other Christians of being children of the devil!

It seems as if Christianity cannot let go of power and needs state and imperial support to survive. Currently, this religion (in its Protestant and Catholic formats) is associated with the American empire (cf. Müller-Fahrenholz 2007; Northcott 2004). These recent acts of President Donald Trump of the USA parading with a Bible in front of a church so as to reflect his viewpoint concerning the protests going on in a number of American cities, reflect the problematic relationship that exists between Christianity, the American empire, and violence.

\section{SUMMARY}

The argument which I tried to develop in the previous sections can be summarised as follows: Throughout human history religion assisted humans in surviving. It played a role in fostering cohesion amongst families, groups, and settler communities. 
However, during the formation of city states, nation states and especially empires, religions were often transformed into ideologies that could assist the ruling elite in imposing one worldview on a diverse group of families, groups, and societies. During this phase religions may become dangerous entities that can cause death and destruction if not kept under constant surveillance by critical devotees and critical scholars. Hunt (2004:249) is correct in stating that "[f] or 99\% of our history religion has been a collective, tribal matter, a matter of belonging and sharing, of treading lightly on the earth and treating all living things with reverence. With the growth of cities, states, and nations came power, class, and wealth".

Looking at the history of Judaism it is evident that Rabbinic Judaism succeeded in taking leave of the Davidic scion ideology as well as the Zion-temple ideology and in making Judaism a family religion again. After the Roman-Jewish Wars of the 1st century, it took leave of state religion and since then it managed to survive and counter the claims of Christians that Christianity superseded Judaism and that God turned his back on them. However, since the experience of the Holocaust during World War II, Jewish people made the fatal mistake of seeking the protection of the American empire. Since the establishment of the state of Israel in 1948, the Israelis allowed state religion to once again lay its hands on Judaism. It soon became evident to everyone that the Israelis are doing to the Palestinians what Christians have done to Jews over the centuries. Judaism is no more a peaceful religion thanks to the Israeli government and the American empire.

Looking back at the history of Christianity, it is evident that the first Christians formed small local communities where believers cared for each other. Northcott (2004:137) is correct in stating that the first Christian churches formed a counterculture within the Roman empire. However, when Christianity became the official state religion of the Roman empire it eventually forgot who Jesus was and what he stood for (Malina 2001:37-111). In the 4th century the Roman empire succeeded in shifting the blame for Jesus' violent death from the empire to the Jews, and Christians fell for this ploy. Looking back, one may say that "[i]t wasn't the early Christians who converted the Empire to their way of thinking, but the Empire that converted them" (Hunt 2004:170). Christians therefore need "to cleanse their faith from its violent imperial legacy" (Northcott 2004:159) if they are serious about being followers of the 'Prince of Peace'. 


\section{REFERENCES}

Armstrong, K. 2014. Fields of Blood: Religion and the History of Violence. The Bodley Head: London.

Becking, B. 2001. Only one God: On possible implications for biblical theology. In: B. Becking, M. Dijkstra, M.C.A. Korpel \& K.J.H. Vriezen. Only One God? Monotheism in Ancient Israel and the Veneration of the Goddess Asherah. The Biblical Seminar 77. Sheffield Academic Press: London. pp. 189-201.

Berndt, H. 2000. Non-Violence in the World Religions: Vision and Reality. SCM: London.

Bernhardt, R. 1994. Christianity without Absolutes. SCM: London.

Carroll, R.P. 1993. War. In: M. Smith \& R.J. Hoffmann (eds.). What the Bible Really Says. HarperSanFrancisco: San Francisco, CA. pp. 147-170.

Carroll, R.P. 1991. Wolf in the Sheepfold: The Bible as a Problem for Christianity. SPCK: London.

Cazelles, H. 1973. The Hebrews. In: D.J. Wiseman (ed.). Peoples of Old Testament Times. The Clarendon Press: Oxford. pp. 1-18.

Collins, J.J. 2005. The Bible after Babel: Historical Criticism in a Postmodern Age. Eerdmans: Grand Rapids, MI.

Collins, J.J. 2019. What Are Biblical Values: What the Bible Says on Key Ethical Issues. Yale University Press: New Haven. https://doi.org/10.2307/j.ctvmd85vm

Coote, R.B. \& Coote, M.P. 1990. Power, Politics, and the Making of the Bible: An Introduction. Augsburg Fortress: Minneapolis, MN.

Davidson, P. 2018. Atlas of Empires: The World's Great Powers from Ancient Times to Today. Fos Chapel Publishers: Chichester.

Deschner, K. 1986. Die Kriminalgeschichte des Christentums (7 volumes). Rowohlt: Hamburg.

Gerstenberger, E.S. 2002. Theologies in the Old Testament. T\&T Clark: London.

Grabbe, L.L. 2007. Ancient Israel: What do we know and how do we know it? T\&T Clark: London.
Handy, L.K. 1995. The Appearance of Pantheon in Judah. In: D.V. Edelman (ed.). The Triumph of Elohim: From Yahwisms to Judaisms. Kok Pharos, Kampen (Contributions to Biblical Exegesis \& Theology 13). pp. 27-34.

Harari, Y.N. 2014. Sapiens: A brief history of humankind. Harvill Secker: London.

Horsley, R.A. 2003. Religion and Empire: People, power, and the life of the Spirit. Augsburg Fortress: Minneapolis, MN.

Hunt, J. 2004. Bringing God back to Earth: Confessions of a Christian publisher. O-Books: Hants.

Jenkins, P. 2014. The Great and Holy War: How World War I became a religious crusade. HarperOne: New York.

Jenkins, P. 2011. Jesus Wars: How four patriarchs, three queens, and two emperors decided what Christians would believe for the next 1,500 years. HarperOne: New York.

Keel, O. 1995. Der zu hohe Preis der Identität, oder von den schmerzlichen Beziehungen zwischen Christentum, Judentum und kanaanäische Religion. In: D. Manfred \& O. Loretz (eds.). Ugarit ein ostmediterranes Kulturzentrum im Alten Orient: Ergebnisse und Perspektiven der Forschung. Ugarit-Verlag: Münster. pp. 95-113.

Kennedy, P. 2006. A Modern Introduction to Theology: New questions for old beliefs. I.B. Tauris: London.

Küng, H. 2009. Islam: Past, present and future. Oneworld Publications: Oxford.

Küng, H. 1995. Christianity: Its essence and history. SCM: London.

Küng, H. 1992. Judaism. SCM: London.

Malina, B.J. 2001. The Social Gospel of Jesus: The Kingdom of God in Mediterranean Perspective. Fortress: Minneapolis, MN.

McKenzie, S.L. 2010. Introduction to the Historical Books: Strategies for reading. Eerdmans: Grand Rapids, MI.

Metaxas, E. 2014. Bonhoeffer Abridged: Pastor, Martyr, Prophet, Spy. Nelson Books: Nashville, TN. 
Müller-Fahrenholz, G. 2007. America's Battle for God: A European Christian Looks at Civil Religion. Eerdmans: Grand Rapids, MI.

Nicholson, E.W. 1967. Deuteronomy and Tradition. Basil Blackwell: Oxford.

Niehr, H. 1995. The Rise of YHWH in Judahite and Israelite Religion: Methodological and religio-historical aspects. In: D.V. Edelman (ed.). The Triumph of Elohim: From Yahwisms to Judaisms. Contributions to Biblical Exegesis \& Theology, 13. Kok Pharos: Kampen. pp. 45-72.

Northcott, M. 2004. An Angel Directs the Storm: Apocalyptic religions and American empire. I.B. Tauris: London.
Pappe, I. 2009. A History of Modern Palestine. Cambridge University Press: Cambridge.

Smith, M.S. 2004. The Memoirs of God: History, memory and the experience of the divine in ancient Israel. Fortress: Minneapolis, MN.

Smith, M. 1987. Palestinian Parties and Politics that Shaped the Old Testament. SCM: London.

Stark, T. 2011. The Human Faces of God: What Scripture reveals when it gets god wrong (and why inerrancy tries to hide it). Wipf and Stock: Eugene, OR.

Wade, N. 2010. The Faith Instinct: How religion evolved and why it endures. Penguin Books: New York. 